\title{
Improving Teachers' Performance of Image and Human Resources through Quality Four Element- One Working and Pattern of Sharpening-Loving- Fostering in the School
}

\author{
Marzuki \\ University of Tanjungpura \\ Pontianak, Indonesia \\ marzuki.pgsduntan@gmail.com
}

\begin{abstract}
Improvement of human resources such as students and teachers is not easy, need the involvement of the entire instrument state and all elements of society. This means that the state cannot be charged to take care of themselves without the support of public education. Similarly, the public, cannot be left to take care of education alone. Transformation or inheritance of the nation's cultural values is very effective if done through education. Transformation of education has been stipulated in the National Education Act No. 20 of 2003. To accelerate the achievement of national education goals inspired by the philosophy and spirit of the nation and the Indonesian Pancasila and the 1945 Constitution and without prejudice to religious values and cultures living in the midst of ASEAN economic community like today. Education should be growing for the next generation of the intelligent nation, creative, skilled, and noble character. In connection with this teacher has a central role in developing the creativity of learners in improving the quality of human resources. For that, every teacher should have the four pedagogic competence, personality, social and professional. Teachers must be able to act as an educator, mentor, coach, motivator, trainer by applying Four Element -one working and "Among" the working with Sharpening system, loving and Fostering. Besides, teachers do not leave the five pillars of education: (i) Learning to believe and to convince the almighty God, (ii) Learning to know, (iii) Learning to do, (iv) Learning to live together and be useful for others, (v) Learning to be, by applying the principles of humanism. It is hoped that this paper can provide a positive contribution to improving human resources - learners, especially in the face of the ASEAN economic community.
\end{abstract}

Keywords- Teachers' Performance; Image and Human Resources; Quality Four Element-One Working; Pattern of Sharpening-Loving-Fostering

\section{INTRODUCTION}

We can not deny that the Indonesian government since independence has been trying to improve the quantity and quality of education in a sustainable manner. The Ideal basic education quality improvement is the implementation of Pancasila, the Constitution of 1945, and the Law on National Education System No. 20 of 2003. The purpose of National Education has been defined in the Law on National Education
System No. 20 of 2003, as follows: "the intellectual life nation of faith, piety, morality, healthy, intelligent, competent, skilled, knowledgeable, creative, independent, democratic, disciplined, responsible. The ten core national goals such as goals to be achieved in the implementation and improvement of the quality of education in Indonesia [1]

The education system in Indonesia in the face of the ASEAN economic community today, adapted to the needs of development in all areas that require the kinds of expertise and skills, and can simultaneously improve productivity, quality and efficiency ". If we start from the formula that education is a conscious effort to develop the personality and abilities of learners, then there are at least two aspects of quality to be assessed are the capabilities and personality aspects. Visibility can be assessed and subdivided into two types: academic skills (knowledge) and skills (physical). To develop the ability of learners fully and directing them to approach self-actualization, the skills involved in the development of creative thinking and acting should not be ignored.

Teaching and learning activities to enhance the learner as qualified human resources teachers need to show "Four Element One Working ("Catur gatra -eka dharma"). Teachers act as an educator, mentor, facilitator, motivator, and inspiration in learning activities with the pattern of sharpeningloving- caring (Asah-asih-asuh $=3 \mathrm{~A}$ ). Teaching and learning activities are carried out with Four of the element with patterns of $3 \mathrm{~A}$, possible positive impact in improving the image of the teacher's performance in school. Within the personal development by learning life and improved performance in a professional teacher with passion, honesty, compassion, responsibility, discipline will have a positive impact on the achievement of improvements in the quality of human resources as the study of students in their school.

\section{ROLE OF TEACHERS IN DEVELOPING CREATIVITY LEARNERS}

Both the psychologist and learning technologists (teacher/lecturer) has been realized that the learners not as a reservoir but the sheer knowledge of learners is a creative 
human creative capability must be developed entirely through the learning process. In developing the creativity of learners, teachers have a position or a central role in learning as a creative manager means as self-motivated individuals and responsible for his ideas.

The image is an impression that the core structure, roundness idea that is techno-structure on elements that is in harmony and balance in the round building. This abstract idea associated with the teacher sounds simple but has a depth process of birth and presence. The teacher is defined as a Wiku, professor, Begawan is a learning resource center, or a place to ask for guidance, a way of solving the problems of life, which has been prevailing assumption hundreds of years ago.

Teachers discussed here is a teacher who is a formal juridical-prepared for the tasks entrusted by the family indirectly and by country. Teachers now is a modern teacher, because he was born due to the demands of the circumstances and needs of the community, he was appointed to the nobleduty tasks such as educating, guiding, educating the children of the nation, by promoting a system of "Among" the learning by adopting sharpering, loving and fostering (Asah -Asih- Asuh) and by: In the front of a situasion we have tobe good example (Ing ngarsa asung tulada); In the meddle we have to build willing (Ing madya mangun karsa; and we support its from behind condition (Tutwuri handayani )".

The accordance with the duties of the teacher, the teacher would have to do with the devotion dharma footing "Catur Gatra -Eka Dharma bakti, Image Master", which means "Catur $=4$, Gatra = element; Eka dharma = one supporting; Image = image; and Master = modern figure who can be followed and imitated. Characteristics or qualities of good teachers in the view/ image learners and society is democratic, like working cooperative, kind, honest, patient, fair, consistent, open, helpful, warm-hearted, polite, humorous, has a wide variety of interests, master teaching materials, flexible, put a good interest to learners. Teachers can act as a facilitator, motivator, innovator, and inspiration to students who are being guided.

\section{PATTERN OF SHARPING-LOVING- FOSTERING (ASAH - ASIH - ASUH )}

In this globalization era, many approaches, strategies, methods or learning model that is used to realize the achievement of learning objectives. There are still many problems we have encountered various implementations of learning, which is partly due to the density of the subject matter and the scarcity of the model or pattern of creative learning and varied so that resulted in the emergence of the tendency of a teacher-centered learning. Such situations lead to the reduced creativity of teachers and learners during the learning activities. These conditions can lead to passive learners and tend to memorize concepts without adequate understanding. All this happened because during the nuances of coaching education implementation operationally by teacher centered focuses on the teaching of the study. Paradigm so tightly held so many teachers are stuck on false beliefs and activities, such as teaching always produces learning. The phenomenon of education as it clearly requires a paradigm shift.
The paradigm with patterns of teaching they should be shifted towards learning which is oriented to the empowerment of learners or learning centered on the learner. In order for the empowerment objectives can be achieved, then the role of the teacher needs to be transferred from the central role in the class into "learning facilitator". The role of the teacher is able to make students feel at home (durable) involved in the learning process and gain something from the study results. Teachers should be able to apply the learning process with five (5) educational pillars: (i) Learning to believe and to convince the almighty God, (ii) Learning to know, (iii) Learning to do, (iv) Learning to live together and be useful for others, (v) Learning to be (Learning to building and self-discovery) [2].

The relating to the management of learning opportunities in the Green School or Green Learning suggested using learning patterns 3A (sharpening, loving and fostering) Pattern of the "Sharpening" illustrated that learning activities centered on the learner. In the process of learning activities occur multidirectional interaction to discuss, learn from each other (sharpening), exchange ideas, doing the same work in learning, mutual respect opinions, each hearing / listening / paying attention, doing joint problem solving, consensus, democracy, and a role-playing. These activities continue to promote mutual trust and courage to develop a brainstorm of mutual respect and process information. These activities are conducted in a conducive environment, safe, comfortable and enjoyable (always green and fun). Teachers can provide exemplary action, nature stimulates children to develop creativity and positive willingness to learn and work hard. The teacher has adopted a "Scientific, Contextual, Constructivistic, humanistic using instructional media, using the strategy, the relevant method. Teachers/lecturers can apply the principle of control and learn that: "Bring their world learners into the world we, and deliver our world into the world of them."

In addition, teachers apply some of the principles as guidelines to improve the image of the teacher's performance, yes it is: (1) Everything speaks means everything that exists in the classroom environment to contain and convey the message of learning, (2) Everything aims. All that happens in the composition, especially regarding the study is aimed at, (3) Experience before naming. In principle, students learn by observing something related to the information that is being studied before they obtain the name of what they learn, discover and formulate concepts or principal, (4) Acknowledge every effort. Learning is a series of business learners in achieving learning goals, and the business itself has risks. Therefore, students deserve recognition for the effort, especially for teachers, working monkey, skills, and their confidence, (5) If feasible studied, it also deserves to be celebrated. This celebration is intended as an expression of recognition of participation, completion of tasks, and the achievement of learners.Techniques to improve "Sharpening pattern" can be used: "TANDUR". (Marking; observations; Naming, Demonstrating, and Celebrating ".The teacher as manager shall develop the creativity of students and help them to explore and develop their potential to the maximum. To enlarge the emergence of creativity in learning to consider the following matters: (1) Develop a high confidence to students and reduce the incidence of fear learners, (2) Giving spirit 
reinforcement, encouragement, the inspiration to students for an independent, scientific, communication and direction, (3) Allowing each student to determine their own and evaluate or reflect themselves against performance, (4) Monitoring should not be too tight or stiff-authoritarian.

Learning is not only done by sharping, but the activity should be with "loving". That is, teachers/lecturers can spread closeness with affection, peace, warmth with sincerity. Not occur heating, insults, ridicule, cornering, scolding, issued dirty words and sentiments or insulting. With affection, it is possible not to be afraid learners engage in activities sharpening. "Fostering". The third pattern is the technique of how to nurture, educate, guide, deliver, to educate students to be selfsufficient after the person who is able to learn. In this activity, the teacher can use the approach: (1) In the front of we have to be an example; teacher anytime anywhere should be able to as an exemplary figure clever, intelligent, kind, skilled. Exemplary such actions, words, and actions consistent, honest, discipline, cooperation, democratic, its hospitality. (2) in the middle we build willing, where the teacher can always put yourself to see, assess the actions of learners. The teacher becomes a facilitator, motivator, inspiration can understand that every student has the ability different but can be developed, (3) Tut wuri handayani, meaning that when learners in problemsolving tasks, perform actions that are not or less precise/wrong, such as actions that violate the rules or contrary to the norms (laws, morals, manners), then the teacher to quickly and accurately take action to correct or improve [3]. Sharpening pattern, loving, foster's when done consistently and continuously with sincerity it will have a positive impact on the image and teacher performance.

\section{CATUR GATRA-EKA DHARMA - IMAgE TEACHER IN THE GREEN SCHOOL}

The four of the element (CG) are (1) Pancasila (central gatra) (2) Hymne teacher, (3) Code of ethics of teachers (gatra form) (4) Teaching profession (10 competencies within the teacher).

\section{A. Pancasila.}

Pancasila is a set of ideas and central element and noble agreement Indonesian nation that is universal. A human who happened to have the teaching profession is human (teacher) who fear in God, he lives with a fair foundation of civilized humanity, and feel as an integral part of the nation, in the sense of the unity of Indonesia. We can able to do - cooperation consensus as a way to solve and resolve a problem. Fair and aspire prosperity of the nation and all the people of Indonesia. From the first principle element (Into the Almighty deity), the embodied meaning (1) Teachers should have the habluminallah- have trust in God, according to the religion and their believing. (2) Teachers should be exemplified in religious practices, and respect the religion and belief in God in others different from themselves. (3) The teacher never imposes religious belief and trust in others. (4) Teachers should have a clear heart, clean quiet on the foundation of sincerity towards a relationship with the God.
The second element is fair civilized humanity, giving instructions : (1) Teachers should look to each other as fellow human beings the same rights and obligations. (2) Be tolerant (3) Do not arbitrarily against others/learners, (4) Dare to defend justice and truth. The third element is the unity of Indonesia, giving instructions: (1) The teacher puts unity, interests, safety above personal / group, (2) Love homeland and nation, willing to sacrifice for the homeland and nation (3) Feeling proud of being Indonesian and landless water. The fourth element is Democracy, led by wisdom in consultative / representative. With every teacher: (1) Giving priority to the interests of the state and society, (2) Prioritize deliberation in making decisions for the common good, (3) Do not impose its will on others, (4) Council to reach a consensus with the spirit of brotherhood, with goodwill responsibility to keep and implement the outcome of deliberation. (5) Meeting with common sense and in accordance with the noble conscience to make decisions and be accountable to God Almighty.(6) Respect for human dignity and the values of truth and justice. The seven element e): Social Justice for all the people of Indonesia, in this precept, is the teacher should: (1) Develop a noble deed and reflects the attitudes of family and kegotong - royongan (2) Be fair, and menjaqga balance between the rights and obligations (3) Respect the rights of others, (4) Do not live lavishly, no excessive luxury life (5) Hardworking, (6) Respect the work of others, (7) Together realizing equitable and fair progress social. With really someone teachers applying pattern-teaser-loving foster framed by the leadership of " Tut wuri handayani and the Pancasila" as a foothold in the central element are unwilling and has belonged to him "the image of the teacher 'and teachers' performance will continue to climb in place naturally.

\section{B. Hymne of Teacher.}

Work of Mr. Sartono, which is the "song" cult of teachers, it is no exaggeration to say so, even though the teacher says. The element latter is partly written as follows:

"Blessed be thou, mother-father teacher. Your name will always live in my heart, all your work will bring to art in my heart. As inscriptions my gratitude to your devotion. You are like a lamp in the darkness. You like dew conditioning in thirst. You are as patriot heroes of the nation."

The contents of this teacher hymn actually contain "core values" for the award-services teachers. However, a teacher is also required as the human personality and virtuous. With hymns teachers, teachers themselves should be able to carry and position ourselves as human/teacher (1) Commendation, can be a role model (example), (2) Devote yourself -with "Tut wuri handayani" sincere. ,(3) Being a lamp in the darkness (lightning, smart creator, educators, (4) Being dew thirst conditioning in both the Green School and Green Learning. (5) Being a patriot, a hero of the nation in realizing "character nation building" - noble characters in the development of the nation. (6) Being implementing and supporting four pillars of nationality: (1) Pancasila ......... Jaya, (2) UUD 1945 .... implemented wholeheartedly (3) NKRI (Homeland) .... fixed price, (4) Unity in Diversity ..... true togetherness. 


\section{Code Ethic of Teacher}

Teacher ethic code originates in Indonesian Teachers Ethik Code, which can be justified because it is produced by the Congress of Indonesian Teachers Association. The material ethic code reflects a set of values about how teachers should teachers should impersonal, behave. By applying this ethics code in the learning process both in the Green School (school environment green, leafy, gardening, conducive, comfortable, safe) and Green learning (learning process with a pattern that is humanistic, constructivist, pattern $3 \mathrm{~A}$ and Tut wuri handayani, fun, meaningful) will be able to improve the image of the better teachers, qualified in the future. The teacher ethics code contains some values concerning the:(1) Consecrated teachers to educate and guide the children into human development of Pancasila. (2) Teachers should be able to implement the curriculum in accordance with the needs of the learner, (3) The teacher must be mastered and have a real profession "Master", both in the task of education, learning, coaching students and schools, (4) The teacher should know about-who and how the learner it, (5) The teacher must be able to build relationships, cooperation among teachers in harmony with teachers, teachers and parents (students) in the true sense (grasp and understand the community), (6) Teachers must be able to build a relationship with the surrounding community, including understanding the environment and good cooperation and regular; (7) Teacher is a state officer in the field of education from the basic of Pancasila state, then when the teacher is the best implementers of educational development efforts of the younger generation to generation student which will be the successor to the life of this nation in the hands of teachers. In this ethics code, Indonesian teachers will mean "Hymn of Teacher" will be realized.

\section{Profession-Teacher}

Profession becomes the fourth gatra in realizing jointly five gatra (Pancasila), Slot Hymne teacher, Slot form (Code ethic of the teacher). Teacher professional development can actually have a well developed through the Teacher Education Based on Capability (PGBK). Professional Competencies include: (1) Mastering the material - field of study, (2) Mastering the deepening field of study, (3) Mastering the field of study methodology, (4) Mastering how to assess areas of study, (5) Mastering the management of teaching and learning programs appropriate instructional- " be able to formulate instructional objectives- be able to use varied teaching methods- be able to select appropriate instructional procedures- To implement a program of learning - teaching- be able to be familiar with the capabilities of learners- $\mathrm{Be}$ able to plan and implement remedial learning, (6) Managing a class by using good action, (7) Creating a climate of good teaching and learning, (8) Can use medium/good teaching and learning resources (9) Mastering the foundations of education (Philosophical (Pancasila/Philosophy of Education) - School as the Institute Reformer), (10) Managing a class with good teaching and learning interactions. By using of preparation, training and the acquisition of a good experience, the master teacher competence can be said that the teacher is professional.

\section{CONCLUSION}

In the process of learning the teacher was instrumental in developing the creativity of learners and learners should be aware that not only as recipients of information, but give it a chance (motivation) as well as the ability to solve problem learning given to him because they are creative human creativity capabilities must be developed through a process education. The creativity of learners is needed in order to plant entrepreneurial spirit and innovative production process.

By using the Four Element -one of responsibility and Pattern of $3 \mathrm{~A}$ and Tutwuri handayani" Insha Allah will improve the image and performance of a good teacher in the future. With four elements of Pancasila, Hymne of the teacher, Code Ethic of Indonesian Teachers and Professionals in the service is dedicated or devoted to the task, then it would actually person admirable teacher of a great nation is Indonesia. That is the figure of the teacher as the noble character of the nation, intelligent, skilled, creative and loyal to the one of responsibility (Eka dharma) and always develop personally as an educator, motivator, and lifelong learning. Amin.

\section{REFERENCES}

[1] Hamka Abdul Azis, 2011. Pendidikan karakter berpusat pada hati. Jakarta : Al Mawardi Prima.

[2] Diana Nomida Musnir, 2015. Papers: Presented in the National Seminar on Education "Education Present And Future Based on Mental Revolution" in PGSD FKIP UNTAN Pontianak, February 26, 2015.

[3] Sri Edy Suwasono dan Sudartomo, 2013. Kebudayaan Mendesain Masa Depan. Yogyakarta: UST-Press. 